\title{
PECULIARITIES OF THE MUTUALLY CAUSED DEVELOPMENT OF PERSONALITY SELF-CONSCIOUSNESS AND SELF-CONCEPT
}

\section{Мар'яна Аипка \\ ОСОБЛИВОСТІ ВЗАЕМОСПРИЧИНЕНОГО РОЗВИТКУ САМОСВІДОМОСТІ І Я-КОНЦЕПЦІї ОСОБИСТОСТІ}

The problem formulation in general. A large number of researches in domestic and foreign psychology are devoted to the problematic of self-consciousness and self-concept. Let's say, O. M. Leontiev gave to these phenomena of reality "high vital importance, because they crown the psychology of personality" [10]. But according to $\mathrm{V}$. A. Romenets who, in the posthumous publication "The History of Psychology of the Twentieth Century", (1998) is more categorical in assessing the place of self-consciousness in the humanitarian discourse: "Psychology, losing the self-consciousness as its main subject, becomes a ghostly discipline." And "an action becomes while self-consciousness of a person is forming" [16, p. 104, 142]. It is noteworthy that within the framework of indicated psychological presentation, the study concerns general theoretical, methodological and applied aspects. The essence, the self-consciousness structure and functions, including the selfesteem, the level of aspirations, the self-respect, the value-sense sphere, etc., belong primarily to the philosophical-psychological format of personality development cognition in ontogenesis.

At the same time, despite the thorough theoretical generalizations and extensive psychological representations about nature, the emergence and development of a human's selfconsciousness, the deployment question of its dynamics and regulation of self-awareness perfect acts remains insufficiently clear. First of all, we talk about studying the time course and, consequently, the rhythmic harmonization in the functional flow of these acts. The problem field of study is also complicated by the fact that the consciousness and the self-consciousness are phenomena unnatural, super-objective, quasisubjective (M. O. Berdyaev, O. M. Loy, M. K. Mamardashvili, A. M. Pyatigorsky, M. Yu. Savelyeva, A. V. Furman). "Mental, - writes V. P. Zinchenko - is likened to a subjectsemantic reality, which, existing in time ..., does not exist in space" [7, p. 116]. A. V. Furman defending the place of consciousness and selfconsciousness in the existential presence of a human in the world as a framework condition for the existence and the development of perfect thinking, activity, cognition and methodologization, states: "Consciousness as a boundary paradox, that is as super-objective and beyondsubjective nothing and at the same time as experientially and historically everything - it is intentional, substantially tense maximality of human existence, which is essentially not statics, but dynamics, not structure, but multifunctionality, not dependence, but freedom of self-practice, not givens, but the existence of subjectivity" [21, p. 32].

Therefore, the reflexive clarification of semantic register of the consciousness sphere will enable to reveal the sensitive periods of its development throughout the life path of a personality. At the same time, there is an urgent need to systemize the phenomena or the empirical evidences of self-consciousness and Self-concept, the reflexive reading of which, by a person, enables an effective interaction with the environment, 
a productive self-determination and self-realization in public life. On the other hand, the problematic case is a proper fulfillment of the analytical procedure delimitation of consciousness and self-consciousness phenomenal outlines, without talking about not yet overcome complexity of distinguishing such mental entities as self-consciousness and Self-concept, Selfconcept and Self-image, Self-concept and Selfdeed. Therefore, the conceptual definitions of these entities require a thorough methodological reflection.

Analysis of recent researches and publications on this issue. The first who substantiated a double nature of self-consciousness was W. James. He singled out recognizable or empirical Ego and cognitive, that is, subjective or our Self, or pure Ego [6]. I. Kant, discussing the issues of self-perception and self-consciousness, believed that the human Self seemed to be double: the Self as a subject of thinking and the Self as an object of perception [8]. In the context of psychoanalytic theory, S. Freud singled out three genetically and functionally different components of personality psyche: Id, Ego and Super-Ego [18]. R. Burns, who mainly studied the global Self-concept as a set of installations, proved the presence of its threecomponent structure: cognitive (Self-image), emotional-estimating (Self-attitude), behavioral (Self-behavior) components [2]. V. A. Petrovsky described four hypostases of the Self (the immanent Self, the ideal Self, the transcendental Self and the transfinite Self) [13]. I. Kon traced the evolution of Self as a scientific problem, combining his researches with the subject of identity, consciousness and self-consciousness of a person [9]. During the last decade O. Ye. Furman (Humeniuk) proposed an author's model of self-creation of the positive-harmonious Selfconcept of a human as the subject, the personality, the individuality, and the development of universality that holds the four-component structure (cognitive (Self-image), emotionalestimating (Self-attitude), deed-creative (Selfdeed) and spontaneous-spiritual (Self-spiritual) components) $[\mathbf{2 0} ; \mathbf{2 2} ; \mathbf{2 5}]$. At the same time, there are many other equally important studies of this issue that deserve attention (V. P. Zinchenko, A. A. Nalchadzhian, V. V. Stolin, T. O. Florenska, A. V. Furman, etc.).

Singling out previously unsolved parts of a general problem which the article is devoted to. Self-consciousness and Self-concept in unity constitute the ontogenetic givens of the inner world of a person, the formation and development of which is carried out organically in its social interaction with the environment, or rather, in a specific relations at the stage of childhood and adolescence with the closest environment. These phenomena acquire a relatively specific stability in adolescence, although throughout their lives they experience distortion, degradation, or harmonization, improvement. This statement is coherent with E. Erickson the concept of psycho-social development (see [29]). That's why with the help of this research we strive to present for the scientific society peculiarities of the mutuallycaused development of self-consciousness, Selfconcept and self-esteem in the personal world of a human.

Goals formulating of the article (presentation of tasks). The aim of the research is to highlight peculiarities of the self-consciousness, Self-concept and self-esteem holistic development as a dialectical complement of general, special and singular in the center of psychospiritual life of a personality. At the same time, the proposed research highlights: a) "consciousness" and "self-consciousness" as the key (categorical) notion of psychological science, b) Self-concept as the center of self-consciousness and ontogenetic reality of the personality's inner world, c) self-esteem as a cell of self-consciousness, which reflects a personal judgment of a human about their own value.

The main research material presentation with full substantiation of the received scientific results. Self-consciousness as a holistic mental new formation appears ontogenetically somewhat later than consciousness. If consciousness is oriented to the whole objective world, then the object of self-consciousness is the person himself, his subjective world and his own individuality. From a psychological point of view, self-consciousness is a complex psychospiritual process, the essence of which is the perception by a personality numerous semantic images and meaningful orientations of himself in different activity and behavior situations, in all possible forms of interaction with other people and in the combination of these images and orientations into a single holistic entity an idea of one's own individual world of Self (see $[12 ; 19]$. However, according to A. V. Furman: “... human life as a constantly restored existence "here and now", which is always present, although temporarily limited by years or 
decades - this is the life of consciousness, without which or beyond which are impossible for a human neither thinking, activity nor reflexive cognition, competent methodologization. Therefore, in this case, it is true both a direct statement, and the opposite one: consciousness is a fertile soil and thus defines the framework and semantic context of making possible the canonical forms or organizations of a specific person life activity; at the same time, on the other hand, by creating and using these forms on the way of own subjective presence in the world, it appears and realizes one way or another an expansion of sense-semantic horizons of light of consciousness situational existence, and therefore the format of its ontofunctional reality is changing, it is spreading its original existence as a framework condition of raising in the bosom of its illumination of new ideals determinations, senses, ideas, thoughts, concepts, concepts-representations, mind-maps etc." [21, p. 26]. Another well-known Ukrainian researcher, P. R. Chamata believed that self-consciousness develops simultaneously with consciousness; at the same time, both of them arise not immediately, not from birth, but in the process of mastering by a child his own body, by transforming ordinary actions into arbitrary [26].

The self-consciousness sphere at the personal level is deployed continuously through time by semantic organizations thanks to the conscious past, the existing present and the future planning. This phenomenon in the timeline of an idealized personified reality is a complex entity, which a person does not fix in a static state, but reflects and transforms the process of its continuous pulsating development. According to I. I. Chesnokova, self-consciousness is a complexly changing two-tier process, which is individualy deployed in the course of subjective time. On its first level, there are single images of oneself, of oneself's behavior, which are connected with a specific situation, with specific a communication, in the basis of which there are mechanisms of self-perception and self-observation. For the second functional level of selfconsciousness it is specifically that the correlation of knowledge about oneself does not occur within the limits of "I and others", but in the system "I and I". The leading methods of this level are the self-cognition and the self-awareness, and the complication of their inner world cognition methods [27].

In general, Self is a dynamic center of consciousness, emotions, judgments, actions, which is organized in a certain integrity, guides the behavior, activity, communication and human actions; thus, the central formation of selfconsciousness is the Self-concept, which is a system of representations, attitudes, actions and existentials of a person in relation to himself [20]. The thesis: a person becomes personality only when a concept of "Self" is formed in him, is considered as a postulate in psychology. In addition, O.M. Leontiev argued that a personality is born twice: in three years, when he says: "I do by myself" (consciousness arises) and in fourteen years when he asks: "What am I?" (self-consciousness is formed) [10]. So the formation of self-consciousness characterizes ontogenetically later period of the productive development of psyche in comparison with consciousness. And this is clearly as self-consciousness enables a person to comprehend himself through awareness of his attitude to the world, through the substantive attitude towards people, through his own common (practical) activity.

S. L. Rubinstein outlines the important stages of the self-consciousness formation in ontogenesis [17]: this is the mastery of own body, the emergence of arbitrary movements, the selfmovement and self-service, the attitude towards the world and others, the experience of life events and personal knowledge. In addition to this, L.S. Vygotsky argues that the emergence of self-consciousness relates to the period of thinking and speech formation, mastering the complex spatial-temporal relationships with adults by a child. Here are some basic theses: "In the broad sense of the word, there is the source of social behavior and consciousness in speech." "An excellent confirmation ... of a thought about the identity of consciousness and social contact mechanisms and that consciousness is like social contact with oneself, may be the training of speech awareness in the deaf people, partly the development in the blind people the perception of tactile reactions." "The most notable is that the speech awareness and social experience arise simultaneously and absolutely parallel" [4, p. 95, 96, 97]. "In general there is no sign without meaning. Sense formation is the main function of the sign. The meaning is wherever the mark is. This is the inner side of the sign. But there is something in consciousness that means nothing." 1) words, germinating into consciousness, change all attitudes and processes; 2 ) the very meaning of the word develops depending on the change of consciousness." "I n g e n e ral, consciousness has 
a s e m a n i c c o n s t r u t i o n ... The sense formation activity of meanings leads to a certain semantic construction of consciousness ... S p e c h is a cor r elation of consciousness, but not thin king" [ibid., P. 162, 164, 165].

So, according to L.S. Vygotsky the essence of consciousness is reduced to the central part of a social experience of a person - to his speech, whereas self-consciousness is an interiorized social knowledge, that is, knowledge of himself and his contacts, which is directed inside his own psycho-spiritual world. Hence it is logically concluded that the formation of self-consciousness as an attributive peculiarity of a personality is an important stage in his psycho-cultural development, which naturally and inevitably arises from the previous stages. Today, there are basis for detailing the given stage development in self-consciousness forms affirmation: from self-cognition to self-attitude, and further to self-regulation (behavior, activity, communication, deed) and, finally, to self-creation of the individual world of Self of personality. Obviously, social causation in the formation of self-consciousness, characterizing by pulsating continuity, invariant modality and multifunctionality, has a temporal diversity of its own existential presence in the world - in the past, in the present, in the future, beyond the horizon of eternal (see in detail [24]). Moreover, the ability to correlate oneself real with oneself in the past and in the future is one of the most important positive formations of the personality self-consciousness, who has become on a selfdevelopment path. The personality existence in time is mostly verbalized in the formula: "I was, I am, I will be, I will remain forever." In addition to this, the own name becomes such first crystal, around which the understanding of the own essence by a person is formed, and then the representation and attitude to his physical appearance, personal world of the individual spiritual core.

According to B. F. Lomov, self-consciousness is an element of consciousness and is characterized by the internal knowledge or belief, which manifests in the understanding and evaluation of its own states, the ability of a human to create himself by interiorizing observations and actions that other people do concerning him [11]. In general, psychological literature has various definitions of the selfconsciousness: 1) this is that segment of a psyche, which is available through internal knowledge and assessment of mental state, when in the focus of subject's attention there is his own inner world (I. S. Kon); 2) this is higher than consciousness level of awareness process of a mental reflection of reality (B. F. Lomov); 3 ) it characterizes the social contact of a person with himself, and therefore is the core of a search and cognition his own Self-concept and identity by him (L. S. Vygotsky); 4) it is the process of conscious changes of oneself and the ability to regulate own behavior in society (V. V. Stolin); 5) at the same time, it is a person's awareness of himself as an individuality, that is, it's a sense comprehension by him of an intentional content of the consciousness components as higher values in the context of his life path (E. Husserl, V. A. Romenets, T. M. Tytarenko, etc.).

Paradoxically, a rather thorough definition of self-consciousness however, can be found in the philosophical system of the great German philosopher G. W. F. Hegel [5], for whom selfconsciousness is an aspect or moment of activity, when the individual merges with the general, so that the Self is appearing, which makes up "We". He singles out t h r e e main s t a g e s of the consciousness development, corresponding to the degrees of the subject maturity and the nature of his interaction with the world.

At the first stage, there is awareness only of the own existence, the own identity and difference from the other objects, that is "the individual self-consciousness". Such an awareness of himself turns inevitably into the recognition of his insufficiency and insignificance in comparison with the infinity of the surrounding world, the consequence of which is a feeling of frustration with the world and a desire for self-realization. Hegel called this stage of self-consciousness development as "self-consciousness which desires".

The second stage is "self-consciousness which recognizes" and suggests the emergence of interpersonal attitude: a person realizes himself existing for another. Facing the other, he finds in it the inherent features for himself, therefore, the own Self acquires for him as a subject a novelty and attracts attention. Consciousness of own individuality grows in this way into the realization of own peculiarity, uniqueness.

The third stage is "a general self-consciousness", it means that the interacted Selves, thanks to appropriation of the general principles, understand not only their differences, but their deep commonality and even identity. This commonality is a "substance of morality" and transforms the individual Self into a part of the objec- 
tive spirit. Hegel emphasizes that an individual opens his own Self not through introspection, but through others in the process of communication and activity, moving from partial to general. Although Self seems completely internal, it is essentially dialogical and not just disclosed, but also generated in the process of communication [5].

According to Hegel, the peak stage of the self-consciousness development, being essentially dialogical, is in unison with the idea of polyphony and dialogism of consciousness, which is disclosed conceptually in the semantic personalism philosophy of M. M. Bakhtin (see [1]). In particular, he writes: "Life by its nature is dialogic. To live means to participate in the dialogue: to ask, to understand, to answer, to agree, etc. In this dialogue, a human takes part in everything and in all life: by his eyes, lips, hands, soul, spirit, all flesh, deeds. He puts whole him into the word. And this word is included into the dialogic tissue of human life, into the world symposium " $[\mathbf{1}, \mathbf{p .} \mathbf{3 1 8}]$. In the context of this thesis development, V. P. Zinchenko notices: "An event of consciousness can be realized only in an availability of two participants, which foresees [the presence] of two not-unison consciousnesses, even if they are combined in one person" [7, p. 77]. Except the dialogicity, self-consciousness is characterized by the constancy of its developmental functioning that is described the best by the term of "identity", which has three main modalities in the sciences about a human - psycho-physiological, social and personal or Ego-identity (I. S. Kon [9]). The first two modalities can be described objectively as something given. According to personal identity, this is impossible, because this phenomenon relates mainly to subjective reality.

In this context, it is appropriate to note the opinion of Hull J., Meteyer K. and other foreign researchers on the existence of personal selfconsciousness, which is associated with unconscious and is manifested in a human's involuntary behavior [30]. This idea is coherent with $\mathrm{K}$. Rogers's conviction that the Self-concept as the core of self-consciousness "...includes unconscious processes, and therefore it can not have a definition and is not a subject to precise scientific research" [20, p. 72].

At the same time, Trapnell P., Campbell J. study the problem of personal self-consciousness in interconnection with reflectivity as a personal feature of a human [31]. Such a combination, in our opinion, is quite logical, since the pro- cesses of self-awareness or reflection are connected with superconscious, where self-consciousness of a person arises as phenomenon of his inner world.

The idea of continuous self-consciousness development throughout life is clearly seen in the works of S. L. Rubinstein: "Self-consciousness is not the original givens inherent to a human, but the product of development ... In the process of this development, a person acquires life experience, not only all new sides of life are revealed before him, but more or less deep reconsideration of life takes place. This process, immersing all life, forms the most sophisticated basic content of a human existence, defines the motives of action and the inner meaning of tasks that he solves in everyday life" [17].

In the process of personality development, self-consciousness acquires new and more complex forms of self-awareness as capabilities, which are integrated into the idea of oneself, is formed more perfect, deep, and adequate image of the own Self. Most psychologists of the XIX century saw in the Self a sensual image that appears on the basis of self-feeling and associations enshrined in memory. It is also established that at the personal level, self-consciousness in the structural ratio is the unity of at least four parties: a) cognitive (self-cognition), b) emotional-valuable (self-attitude), c) psycho-regulative (self-regulation), d) reflexive (self-awareness), which are determined by a human activity and actions. The image of Self covers a certain set of components (an idea of my body, my mental properties, moral qualities, etc.), their specific content and significance varies depending on social and psychological conditions and states. In addition, a person does not just "open" himself, but also actively becomes as personality, develops and asserts himself in actions. The awareness of own abilities changes his self-esteem and the level of aspirations, which are not only revealed but also unfolded, improved in activity, communication, and accomplishment.

It is noteworthy that the self-esteem from the first moments of its origin participates implicitly in the regulation of behavior, is a significant component of the self-consciousness structure, defining and directing the specifically entire process of self-regulation. Moreover, the result of the last one is correlated directly with the adequacy, stability and depth of self-esteem, the dynamics of its development [27]. It is precisely around self-esteem and image of the 
Self as the core of self-consciousness arises eventually the depth and intensity of the emotional-valuable attitude of a person to himself. Various feelings, emotional states, experienced in different periods and in different situations of life, form the emotional "fund" of self-consciousness, enriching contently with the system of emotional-valuable self-attitudes. That is why the process of self-esteem establishing does not have any limit in time, as a person develops constantly - the content of his worldview, the ways of self-evaluation, the extent of his participation in the regulation of behavior, activity, and actions are rebuilt.

Personality reaches the highest degree of selfcognition when the notion of himself is formed not only in the present but also in the future. As he contains the forces, skills, desires, intentions that are not yet realized, exist as the psychic tendencies, and therefore require their manifestation and actualization. So, under the influence of time factor, the structure of selfconsciousness changes - for the first time in the development of a personality, his individual forms of behavior become the internal motives for activity and actions. Hence, self-consciousness appears as a complex integrative quality, attribute of his psycho-spiritual involvement in existence. On the one hand, it captures the outcome of a person's mental development at certain stages, on the other it acts as an internal regulator of social behavior, and, moreover, establishes a certain balance between the internal influence, mental state of a personality and forms of his diverse subjective interaction in society. As a unit of self-consciousness, it reflects the level of development of a self-respect sense in a person, a sense of self-value and a positive attitude to all that is a part of his sphere of the Self; it is manifested in conscious judgments, when a person seeks to determine his extraordinary significance, comprehending the image of the own Self, self-reporting about the level of his demands and resorting to self-control [3].

The dynamism of self-consciousness, the interdependent change of its components in time, is confirmed by the study of $\mathrm{K}$. Rogers, who in the structure of self-esteem singles out real and ideal Self, starting from the experience of own conscious experiences, obtained through the method of introspection [15]. In general, this well-known psychologist highlights four parameters of Self: a real representation of oneself, an idea of the own social role, an idea of the own physical condition and health, an idea of the own goals, plans and desires for the future.
At the same time, in his applied theorizing, Selfconcept is a complex-dynamic integral formation and a central link of personality self-consciousness, covering the representation about his own characteristics and abilities, the possibilities of interaction with other people and all the world, about the goals and ideas that have either positive or negative direction.

Therefore, "in the inner world of a human and his self-consciousness, in particular, Selfconcept is an important structural component of psychological self-organization, which performs the function of precondition and consequence of effective social interaction and the quality of life in general ... Self-concept that arises on the basis of the relationship of a personality with society, determines the actual system of his self-perception and sets the moral and ethical limits of real behavior. So, as a central formation of the ontogenetic development, it characterizes not only the features of self-vision, but also the potential action, the practical experience and the creation of the closest society and his own Self" [25, p. 49], and therefore "actualizes the potential of the motivational, intellectual, volitional subsystems ... of a personality" [28, p. 116].

Thus, the primary task is to study the processes and conditions of personality inner world self-development and self-disclosure, the possibilities of realizing by him his own potential, his self-actualization. This is achieved mainly through the channel of self-awareness and complication and harmonization of the selfconsciousness central link - the Self-concept, which directs personality primarily both to the situational self-estimation and level of aspirations, and to fateful personal and professional choices, actions and lifestyles.

\section{CONCLUSIONS AND PERSPECTIVES OF THE FURTHER RESEARCHES}

1. Self-consciousness is extremely complicated formation of a human inner world that enables self-comprehension of himself through the awareness of his attitude to the world, an important element of the personality psychocultural development, which deploys in a person's time-space and promotes his progress through morality, or vice versa, degradation in case of absence of a positive self-perception of the world and self-attitude to it.

2. Self-concept is an integral core or basic formation of a human self-consciousness, which characterizes the orientation of his psycho-spiri- 
tual capacities and potentials to actualize the cognition and design of one's own inner world; therefore, it is a complex structural and multifunctional organization of a person that holds the cognitive, emotional-estimating, deed-creative and spontaneous-spiritual components, and at the same time mutually harmonizes the selfesteem, the level of aspirations, the Self-image, the Self-attitude, the Self-deed, the Self-spiritual.

3. Self-esteem is a significant component of the self-consciousness and at the same time is a central component of the Self-concept. It does not constitute a constant value, as it changes according to circumstances. Thanks to it, a sense of self-respect of a person, his feelings and experiences of the own value, as well as a positive attitude to everything that is a part of the actual sphere of the Self is reflected. The process of establishing self-esteem does not have a clearly defined limit, because a personality is constantly evolving: his perception of the world, the degree of participation in behavior regulation, the content and quality of actions and life in general is changing.

4. The development and formation of selfconsciousness, Self-concept and self-esteem is realized in the flowing time-space of social interaction of a human with the environment during life according to laws of dialectical complementary of general, special, individual; primarily it concerns specific situations and relations at the stage of childhood and adolescence. In the holistic dynamics, they form an ontogenetic reality of the internal psycho-spiritual world of a personality, which determines not only the successness or failure in the work and rest, but also the productivity of his life and even creative path in general.

\section{LITERATURE}

1. Бахтин М.М. Эстетика словесного творчества / Михаил Михайлович Бахтин. - М.: Искусство, 1979. $424 \mathrm{c}$.

2. Бернс Р. Развитие Я-концепции и воспитание / Роберт Бернс; пер. с англ. - М. : Прогресс, 1986. - 421 с.

3. Болотова А.К. Развитие самосознания личности: временной аспект / А.К. Болотова // Вопросы психологии. - 2006. - №2. - С. $116-125$.

4. Виготский Л.С. Собрание сочинений: В 6-ти т. Т. 1. Вопросы теории и истории психологии / Лев Семёнович Выготский; под ред. А.Р. Лурия, М.Г. Ярошевского. - М.: Педагогика, 1982. - 488 с., ил. (Акад. пед. наук СССР).

5. Гегель Г.В.Ф. Энциклопедия философских наук / Георг Вильгельм Фридрих Гегель. - Т.3. Философия духа / отв. ред. Е.П. Ситковский; ред. коллегия: Б.М.
Кедров и др. - М.: Мысль, 1977. - 471 с. - (АН СССР Ин-т философии. Филос. наследие).

6. Джемс У. Психология / Уильям Джемс: [пер. с англ.; под ред. Л.А. Петровской]. - М.: Педагогика, 1991. -368 с.

7. Зинченко В.П. Сознание и творческий акт / Владимир Петрович Зинченко. - М.: Языки славянских культур, 2010. - 592 с.: ил.

8. Кант I. Критика чистого розуму / Іммануїл Кант; пер. 3 нім. та прим. І. Бурковського. - К.: Юніверс, 2000. $-504 \mathrm{c}$.

9. Кон И.С. В поисках себя: Личность и ее самосознание / Игорь Семенович Кон. - М.: Политиздат, 1984. $-335 \mathrm{c}$.

10. Леонтьев А.Н. Деятельность. Сознание. Личность / Алексей Николаевич Леонтьев. - М.: Политиздат, 1975. - $304 \mathrm{c}$.

11. Ломов Б.Ф. Об исследовании законов психики / Борис Федорович Ломов // Психологический журнал. - 1980. - Т.1, №1. - С. 157-189.

12. Основи психології : підруч. [для студ. вищ. навч. закл.] / за заг. ред. О.В. Киричука, В.А. Роменця. - [2-е вид., стереотип.]. - К.: Либідь, 1996. - 632 с.

13. Петровский B.A. Личность в психологии: парадигма субъективности / Вадим Артурович Петровский. - Ростов-на-Дону: Феникс, 1995. - 512 с.

14. Психология самосознания: [хрестоматія] / [ред.сост. Д.Я. Райгородский]. - Самара: Изд. Дом "Бахрар-М", 2000.-672 с.

15. Роджерс К.Р. Взгляд на психотерапию. Становление человека / Карл Роджерс; пер. с англ. [общ. ред. и предисл. Исениной Е.И.]. - М.: Изд. группа "Прогресс", "Универс", 1994. - 480 с.

16. Роменець В.А. Історія психології XX століття: навч. посібник / В.А. Роменець, І.П. Маноха; вст. ст. В.О. Татенка, Т.М. Титаренко. - Вид. 3-те. - К.: Либідь, 2017. - $1056 \mathrm{c}$.

17. Рубинштейн С.Л. Основы общей психологии: учеб. [для психологов, педагогов, философов] / Сергей Леонидович Рубинштейн. - СПб.: Питер, 2000. - 712 с.: ил. - (Серия "Мастера психологии").

18. Фрейд 3. "Я” и “Оно” / Зигмунд Фрейд // “я” и "Оно”: в 2-х кн. - Тбилиси: Мерани, 1991. - Кн. 1. - С. $351-392$.

19. Фурман А.А. Психологія смисложиттевого розвитку особистості: [монографія] / Анатолій Анатолійович Фурман. - Тернопіль: ТНЕУ, 2017. - 508 с.

20. Фурман А.В. Психологія Я-концепції: Навч. пос. / Анатолій Васильович Фурман, Оксана Євстахіївна Фурман (Гуменюк). - Львів: Новий світ-2000, 2006. $360 \mathrm{c}$.

21. Фурман A.B. Свідомість як рамкова умова пізнання і методологування / Анатолій В. Фурман // Психологія і суспільство. - 2017. - №4. - С. 16-38.

22. Фурман (Гуменюк) О.С. Психологія Я-концепції: [навч. пос.] / O.С. Фурман (Гуменюк). - Тернопіль: Економічна думка, 2004. - 310 с.

23. Фурман (Гуменюк) О. Методологія пізнання освітнього вчинку в контексті інноваційно-психологічного клімату / Оксана Фурман (Гуменюк) // Психологія і суспільство. - 2012. - №1. - С. 47-81.

24. Фурман O.С. Простір і час у психологічному 
дискурсі / Оксана Свстахіївна Фурман // Психологія суспільство. - 2017. - №1. - С. 79-132.

25. Фурман O.С. Я-концепція як предмет багатоаспектного теоретизування / Оксана Свстахіївна Фурман // Психологія і суспільство. - 2018. - №1-2. - С. 38-67.

26. Чамата П.Р. К вопросу о генезисе самосознания личности / П.Р. Чамата // Проблемы сознания: Материалы симпозиума. Март-апрель 1966 / отв. ред. B.М. Банщиков. - М.: Наука, 1966. С. 228-239.

27. Чеснокова И.И. Проблема самосознания в психологии: [монография] / Ирина Ивановна Чеснокова. - М.: Наука, 1977. - 144 с.

28. Шандрук $C$. Теоретична модель розвитку професійних творчих здібностей особистості практичного психолога / Сергій Шандрук // Психологія і суспільство. - 2015. - №4. - С. 107-121.

29. Erikson E.H. The concept of ego identity // Amer. Psychoanal. Assn. - 1956. - №4. - P. 56-121.

30. Hull J.G., Slone L.B., Meteyer K.B., Matthews A.R. The nonconsciousness of self-consciousness / J.G. Hull., L.B. Slone, K.B. Meteyer, A.R. Matthews // Journal of Personality and Social Psychology. - 2002. - №83(2). - P 406-424.

31. Trapnell P.D., Campbell J.D. Private selfconsciousness and the five-factor model of personality: Distinguishing rumination from reflection / P.D. Trapnell, J.D. Campbell // Journal of Personality and Social Psychology. - 1999. - № 76(2). - P. 284-304.

\section{REFERENCES}

1. Bakhtin M.M. Estetika slovesnogo tvorchestva. - M.: Iskusstvo, 1979. - $424 \mathrm{~s}$.

2. Berns R. Razvytye Ya-kontseptsyy i vospytanye / Robert Berns; per. s anhl. - M. : Prohress, 1986. - 421 s.

3. Bolotova A.K. Razvitiye samosoznaniya lichnosti: vremennoy aspekt / A.K. Bolotova // Voprosy psikhologii. - 2006. - №2. - S. 116-125.

4. Vigotskiy L.S. Sobraniye sochineniy: V 6-ti t. T. 1. Voprosy teorii i istorii psikhologii / pod red. A.R. Luriya, M.G. Yaroshevskogo. - M.: Pedagogika, 1982. - 488 s., il. (Akad. ped. nauk SSSR).

5. Hehel H.V.F. Entsyklopedyia fylosofskykh nauk / Heorh Vylhelm Frydrykh Hehel. - T.3. Fylosofyia dukha / Otv. red. E.P. Sytkovskyi; red. kollehyia: B.M. Kedrov y dr. - M.: Mysl, 1977. - 471 s. - (AN SSSR. Yn-t fylosofyy. Fylos. nasledye).

6. Dzhems U. Psykholohyia / Uyliam Dzhems: [per. s anhl.; pod red. L.A. Petrovskoi]. - M.: Pedahohyka, 1991. $-368 \mathrm{~s}$

7. Zinchenko V.P. Soznaniye i tvorcheskiy akt. - M.: Yazyki slavyanskih kul'tur, 2010. - 592 s.: il.

8. Kant I. Krytyka chystoho rozumu: [per. z nim. ta prym. I. Burkovskoho]/ I. Kant. - K.: Yunivers, 2000. - 504 s.

9. Kon Y.S. V poyskakh sebia: Lychnost y ee samosoznanye/ Ihor Semenovych Kon. - M.: Polytyzdat, 1984. $-335 \mathrm{~s}$

10. Leontev A.N. Deiatelnost. Soznanye. Lychnost / Aleksei Nykolaevych Leontev. - M.: Polytyzdat, 1975. $304 \mathrm{~s}$.

11. Lomov B.F. Ob issledovanii zakonov psykhiki / Borys Fedorovych Lomov // Psykholohycheskyi zhurnal.
- 1980. - T.1, №1. - S. 157-189.

12. Osnovy psykholohiyi : pidruch. [dlya stud. vyshch. navch. zakl.] / za zah. red. O.V. Kyrychuka, V.A. Romentsya. - [2-e vyd., stereotyp.]. - K. : Lybid, 1996. $632 \mathrm{~s}$.

13. Petrovskyi V.A. Lychnost v psykholohii : paradihma subyektivnosti / Vadim Arturovych Petrovskyi. - Rostovna-Donu: Fenyks, 1995. - $512 \mathrm{~s}$.

14. Psykholohyia samosoznanyia: khrestomatyia / [red.sost. D.Ia. Raihorodskyi]. - Samara: Izd. Dom "BakhrarM", 2000. -672 s.

15. Rodzhers K.R. Vzghliad na psykhoterapyiu. Stanovlenye cheloveka / Karl Rodzhers; per. s anhl. [obshch. red. i predysl. Isenynoi E.Y.]. - M.: Izd. hruppa "Prohress", "Unyvers", 1994. - 480 s.

16. Romenets V.A., Manokha I. P. Istoriya psykholohiyi XX stolittya: navch. posibnyk / V.A. Romenets, I.P. Manokha; vst. st. V.O. Tatenka, T.M. Tytarenko. - Vyd. 3-tye. - K.: Lybid, 2017. - 1056 s.

17. Rubynshtein S.L. Osnovy obshchei psykholohii : ucheb. [dlia psykholohov, pedahohov, filosofov] / Serhei Leonydovych Rubinshtein. - SPb. : Piter, 2000. - 712 s. : yl. - (Seryia "Mastera psikholohii").

18. Freid Z. "Ia" y "Ono" / Zyhmund Freid // "Ia" y "Ono": v 2-kh kn. - Tbylysy: Merany, 1991. - Kn. 1. - S. 351-392.

19. Furman A.A. Psykholohiya smyslozhyttyevoho rozvytku osobystosti: [monohrafiya] / Anatoliy Anatoliyovych Furman. - Ternopil: TNEU, 2017. - 508 s.

20. Furman A.V., Furman (Humeniuk) O.Ye. Psykholohiia Ya-kontseptsii: Navch. pos. / Anatolii Vasylovych Furman, Oksana Yevstakhiivna Furman (Humeniuk). Lviv: Novyi svit-2000, 2006. - 360 s

21. Furman A.V. Svidomist yak ramkova umova piznannya i metodolohuvannya / Anatoliy Furman // Psykholohiya i suspilstvo. - 2017. - №4. - S. 16 - 38.

22. Furman (Humeniuk) O.Ye. Psykholohiia Yakontseptsii: navch. pos. / O.Ye. Furman (Humeniuk). Ternopil: Ekonomichna dumka, 2004. - 310 s.

23. Furman (Humenyuk) O. Metodolohiya piznannya osvitnoho vchynku v konteksti innovatsiynopsykholohichnoho klimatu / Oksana Furman (Humenyuk) // Psykholohiya i suspilstvo. - 2012. - №1. - S. 47 - 81.

24. Furman O. Ye. Prostir i chas u psykholohichnomu dyskursi / Oksana Yevstakhiivna Furman // Psykholohiya i suspilstvo. - 2017. - №1. - S. 79 - 132.

25. Furman O.Ye. Ya-kontseptsiya yak predmet bahatoaspektnoho teoretyzuvannya / Oksana Yevstakhiivna Furman // Psykholohiya i suspilstvo. - 2018. - №1-2. - S. $38-67$.

26. Chesnokova Y.Y. Problema samosoznanyia v psykholohii: [monohrafyia]/ Iryna Ivanovna Chesnokova. - M.: Nauka, 1977. - 144 s.

27. Chamata P.R. K voprosu o genezise samosoznaniya lichnosti / // Problemy soznaniya: Materialy simpoziuma. Mart-aprel 1966/ Otv. red. V.M. Banshchikov. M.: Nauka, 1966. S. $228-239$.

28. Shandruk S. Teoretychna model rozvytku profesiynyh tvorchyh zdibnostey osobystosti praktychnoho psykholoha / Serhiy Shandruk // Psykholohiya i suspilstvo. - 2015. - №4. - S. 107 - 121.

29. Erikson E.H. The concept of ego identity // Amer. 
Psychoanal. Assn. - 1956. - №4. - P. 56-121.

30. Hull, J.G., Slone, L.B., Meteyer, K.B., \& Matthews, A.R. (2002). The nonconsciousness of self-consciousness. Journal of Personality and Social Psychology, 83(2), 406-424.

31. Trapnell, P.D., \& Campbell, J.D. (1999). Private selfconsciousness and the five-factor model of personality: Distinguishing rumination from reflection. Journal of Personality and Social Psychology, 76(2), 284-304.

\section{АНОТАЦІЯ}

\section{Липка Мар'яна Михайлівна.}

Особливості взаємоспричиненого розвитку самосвідомості і Я-концепції особистості.

У статті висвітлено особливості холістичного розвитку самосвідомості, Я-концепції та самооцінки як діалектичного взаємодоповнення категорій загального, особливого та одиничного в осередді психодуховного життя особистості. При цьому самосвідомість розглядається як цілісне психічне новоутворення, яке онтогенетично виникає пізніше свідомості і суть якого полягає в самоусвідомленні. Динамічним центром свідомості є Я, що керує поведінкою, спілкуванням та вчинками людини, а центральним утворенням самосвідомості - Я-концепція, що становить систему уявлень (Я-образ), ставлень (Я-ставлення), дій (Я-вчинок) взаємозалежну сукупність установок особистості, які спрямовані на саму себе. Доведено, що самооцінка являє собою “клітинку” самосвідомості, сутнісно відображає цінність та значущість, котрі особа приписує собі. Здійснено конструктивний аналіз трьох етапів розвитку самосвідомості, які виокремив німецький філософ Г. В. Ф. Гегель, - одинична, особлива і загальна виміри самосвідомості. Встановлено, що на особистісному рівні самосвідомість у структурному співвідношенні становить єдність чотирьох сторін котрі зумовлені вчинками людини: пізнавальної (самопізнання), емоційно-ціннісної (самоставлення), психорегуляційної (саморегуляція), рефлексивної (самоусвідомлення).

Ключові слова: особистість, свідомість, самосвідомість, Я-концепція, самооцінка, рівень домагань, глобальна Я-концепція, позитивно-гармонійна Яконцепція, мовлення як корелят свідомості, здатність до самоусвідомлення, самосприйняття, самотворення.
ANNOTATION

\section{Mariana Lypka.}

Peculiarities of the mutually caused development of personality self-consciousness and Self-concept.

The article highlights peculiarities of the holistic development of self-consciousness, Self-concept and selfesteem as a dialectical complementary of general, special and individual categories in the core of a personality psycho-spiritual life. At the same time, self-consciousness is considered as a holistic psychic new formation, which arises ontogenetically later than consciousness, and the essence of which lies in self-awareness. The dynamic center of consciousness is the Self, which controls the behavior, communication and actions of a human, and the central formation of self-consciousness is the Self-concept that constitutes a system of representations (Self-image), attitudes (Self-attitude), actions (Self-deed) an interconnected set of personality installations that are directed towards himself. It is proved that self-esteem represents a "cell" of self-consciousness, essentially reflects the value and significance that a person attributes to himself. It was made a constructive analysis of the three stages of the selfconsciousness development, which was singled out by the German philosopher G. W. F. Hegel: a single, special and general dimension of self-consciousness. It is established that at the personal level, self-consciousness in the structural ratio is a unity of four sides which are caused by a human actions: cognitive (the self-cognition), emotional-valuable (the self-attitude), psycho-regulative (the self-regulation), reflexive (the self-awareness).

Key words: personality, consciousness, self-consciousness, self-concept, self-esteem, level of aspirations, global Selfconcept, positive-harmonic Self-concept, speech as a correlate of consciousness, ability to self-awareness, selfperception, self-creation.

Рецензенти:

А. психол. н., проф. Карпенко З.С., д. психол. н., проф. Шевченко Н.Ф.

Надійшла до редакції 20.09.2018. Підписана до друку 25.09.2018. 